\title{
Gorontalo
}

Journal of Government and Political Studies

Volume 4 - NO. 1 - April 2021

P-ISSN: 2614-2120 E-ISSN: 2614-2104

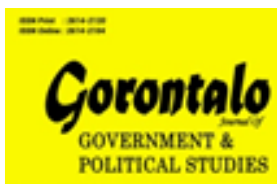

\section{Evaluasi Kebijakan Program Keluarga Harapan di Kecamatan Karawang Barat Kabupaten Karawang}

\author{
Ade Kurniawan, \\ Lukmanul Hakim, \\ Rachmat Ramdani \\ Program Studi Ilmu Pemerintahan, Fakultas Ilmu Sosial dan Ilmu Politik \\ Universitas Singaperbangsa Karawang \\ Jalan. HS. Ronggowaluyo, Puseur Jaya, Kab. Karawang \\ adekrnwn16@gmail.com
}

Received: 19th November 2020; Revised: 09th March 2021; Accepted: 09th March 2021

\begin{abstract}
This study aims to describe how the evaluation of the Family Hope Program, West Karawang District. This research is a qualitative research using the case study method. Data collection techniques use interviews with informants as objects of information that aim to achieve goals in order to obtain information in research. The types of data used in this study are primary data and secondary data obtained from interviews with informants in this study. The author uses the policy evaluation theory according to William N Dunn as a reference for analyzing which consists of aspects of effectiveness, efficiency, adequacy, leveling, and accuracy. The results showed that the evaluation of the implementation of the Family Hope Program Policy in Karawang District was judged by several evaluation indicators as a whole that had met, namely, effectiveness, adequacy. Meanwhile, other indicators have not met, namely efficiency, leveling and accuracy. Several obstacles were encountered in the implementation of the Family Hope Program, namely the lack of PKH resources, difficulty in changing the mindset of KPM, and the uneven distribution of aid.
\end{abstract}

Keywords: Evaluation; PKH Program; West Karawang District

\section{ABSTRAK}

Penelitian ini bertujuan mendeskripsikan bagaimana evaluasi Program Keluarga Harapan Kecamatan Karawang Barat. Penelitian ini merupakan penelitian kualitatif dengan menggunakan metode studi kasus. Teknik pengumpulan data menggunakan wawancara dengan informan sebagai objek informasi yang bertujuan untuk mencapai tujuan guna memperoleh informasi dalam penelitian. Jenis data yang digunakan dalam penelitian ini adalah data primer dan data sekunder yang diperoleh dari wawancara dengan informan dalam penelitian ini. Penulis menggunakan teori evaluasi kebijakan menurut William N Dunn sebagai acuan menganalisis yang terdiri dari aspek efektifitas, efisiensi, kecukupan, perataan, dan ketepatan. Hasil penelitian menunjukkan bahwa evaluasi pelaksanaan Kebijakan Program Keluarga Harapan di Kecamatan Karawang dinilai dari beberapa indikator evaluasi secara keseluruhan sudah memenuhi yaitu, efektifitas, kecukupan. Sedangkan indikator lainnya masih belum memenuhi yaitu efisiensi, perataan dan ketepatan. Pelaksanaan Program Keluarga Harapan masih ditemui beberapa kendala yaitu kurangnya Sumber Daya PKH, susahnya merubah cara pola pikir KPM, dan persebaran bantuan yang tidak merata.

Kata Kunci: Evaluasi; Program PKH; Kecamatan Karawang Barat. 


\section{PENDAhUluan}

Kemiskinan di Indonesia masih merupakan permasalahan paling besar karena sampai saat ini pemerintah masih belum dapat dientaskan atau diatasi. Menurut data Badan Pusat Statistik (BPS) tahun 2019, jumlah penduduk Indonesia yang hidup dibawah garis kemiskinan dan hidup dalam kondisi tidak layak mencapai 24, 79 juta orang atau sekitar setengah dari seluruh rumah tangga tetap berada disekitar garis kemiskinan nasional, dengan pendapatan per kapita per bulan sebesar Rp440.538,-.Dalam upaya mengentaskan kemiskinan, pemerintah (policy maker) telah menetapkan Undang-Undang Republik Indonesia Nomor 13 Tahun 2011 tentang Penanganan Fakir Miskin. Lebih lanjut di jelaskan dalam Pasal 1 bahwa Fakir Miskin adalah orang yang sama sekali tidak mempunyai sumber mata pencaharian dan/atau mempunyai sumber mata pencaharian tetapi tidak mempunyai kemampuan memenuhi kebutuhan dasar yang layak bagi kehidupan dirinya dan/atau keluarganya.

Untuk mengatasi keadaan fakir miskin tersebut, upaya penanganannya secara terarah, terpadu, dan berkelanjutan baik oleh Pemerintah, Pemerintah Daerah, maupun masyarakat dalam bentuk kebijakan, program dan kegiatan pemberdayaan, pendampingan serta fasilitasi untuk memenuhi kebutuhan dasar setiap warga negara, telah tertuang dalam Peraturan Pemerintah Republik Indonesia Nomor 63 Tahun 2013 tentang Pelaksanaan Upaya Penanganan Fakir Miskin Melalui Pendekatan Wilayah.Dalam rangka meningkatkan kualitas hidup keluarga miskin dan rentan melalui peningkatan aksesibilitas terhadap layanan kesehatan, pendidikan, dan kesejahteraan sosial, memerlukan suatu program perlindungan sosial yang terencana, terarah, dan berkelanjutan menjadi dasar pertimbangan ditetapkannya Peraturan Menteri Sosial Republik Indonesia Nomor 1 tahun 2018 tentang Program Keluarga Harapan.

Program Keluarga Harapan yang selanjutnya disingkat $\mathrm{PKH}$ adalah program pemberian bantuan sosial bersyarat kepada keluarga dan/atau seseorang miskin dan rentan yang terdaftar dalam data terpadu program penanganan fakir miskin, diolah oleh Pusat Data dan Informasi Kesejahteraan Sosial dan ditetapkan sebagai keluarga penerima manfaat PKH.

Dalam Pedoman Pelaksanaan PKH Tahun 2019, telah dinyatakan bahwa tahapan pencapaian tujuan tersebut dalam jangka pendek $\mathrm{PKH}$ diharapkan mampu membantu keluarga miskin (KM) mengurangi beban pengeluaran. Pada jangka menengah PKH diharapkan mampu menciptakan perubahan perilaku peserta dalam mengakses layanan kesehatan, pendidikan dan kesejahteraan sosial sehingga menghasilkan generasi yang Iebih sehat dan cerdas. Dalam jangka panjang $\mathrm{PKH}$ diharapkan dapat memutus rantai kemiskinan antar generasi.

Sejak tahun 2008 PKH sudah dilaksanakan di Kabupaten Karawang. Menurut BPS Karawang 2019, dibalik perkembangan yang pesat, kehidupan sosial, dan ekonomi di Kabupaten Karawang belum dikelola dengan baik,sehingga masih masuk dalam kriteria daerah miskin yang didukung dengan jumlah penduduk yang hidup dibawah garis kemiskinan mencapai sebanyak 173.66 ribu jiwa. Pemerintah Daerah Kabupaten Karawang selama ini telah melaksanakan PKH untuk membantu masyarakat miskin memenuhi kebutuhannya berupa pemberian dana bantuan antara lain untuk menyekolahkan anak dan mendapatkan fasilitas kesehatan yang layak karena 
PKH merupakan salah satu upaya pemerintah dalam proses pelembagaan perlindungan sosial dan kesejahteraan bagi masyarakat miskin. Menurut data BPS Karawang jumlah penduduk miskin di Kabupaten Karawang tahun 20162019, sebagaimana grafik 1 berikut.

\section{Grafik 1 Jumlah penduduk di Kabupaten Karawang, Tahun 2016-2019}

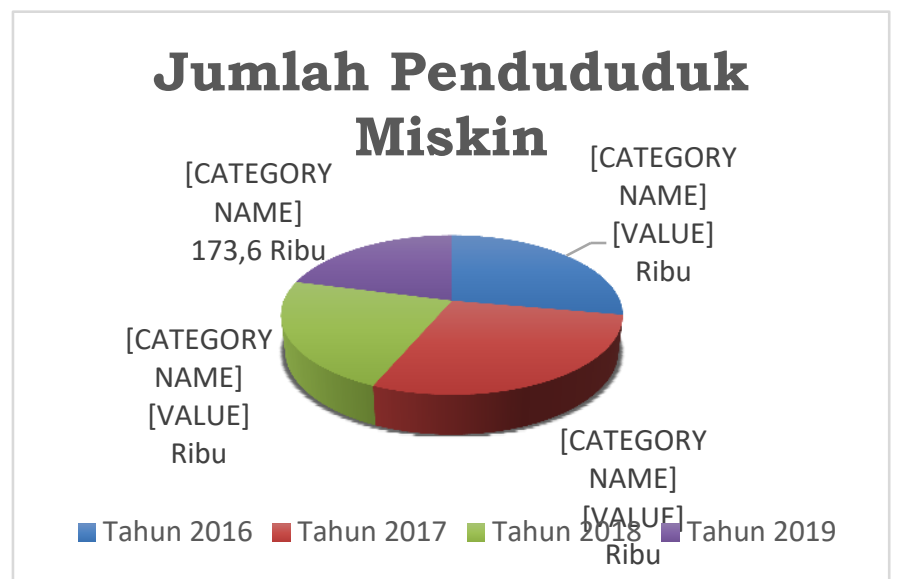

Sumber: Badan Pusat Statistik Kabupaten Karawang

Pada daftar grafik 1 diatas dapat dijelaskan bahwa jumlah penduduk miskin di Kabupaten Karawang sejak tahun 2016 sebanyak 230,6 ribu jiwa dan pada tahun 2017 megalami kenaikan sebesar 236,8 ribu jiwa masyarakat miskin. Namun pada 2019, mengalami penurunan cukup signifikan menjadi sebanyak 173,6 ribu orang atau menurun sebesar $8,06 \%$, faktor-faktor yang mempengaruhi penurunan kemiskinan, pemerintah telah banyak menggulirkan program bantuan sosial di Kabupaten Karawang yang dianggap ampuh menurunkan tingkat kemiskinan antara lain Bantuan Pangan Non Tunai BPNT, Beras Sejahtera (Rastra), dan Program Keluarga Harapan (PKH).

Pada tahun 2019 penerima PKH sebanyak 87.768 jiwa yang tersebar di 30 kecamatan di Kabupaten Karawang, termasuk di dalamnya Kecamatan Karawang Barat yang menjadi lokus penelitian. Dari data yang diperoleh, jumlah penerima PKH paling banyak yaitu Kecamatan Karawang Barat Kabpuaten Karawang sebanyak 5100 jiwa. Berdasarkan informasi yang diperoleh dari BPS Karawang jumlah penduduk di Kecamatan Karawang Barat sebanyak 196.285 jiwa. Jumlah Desa/Kelurahan yang mendapatkan bantuan PKH Di Kecamatan Karawang Barat, sebagaimana tabel 1 berikut. 


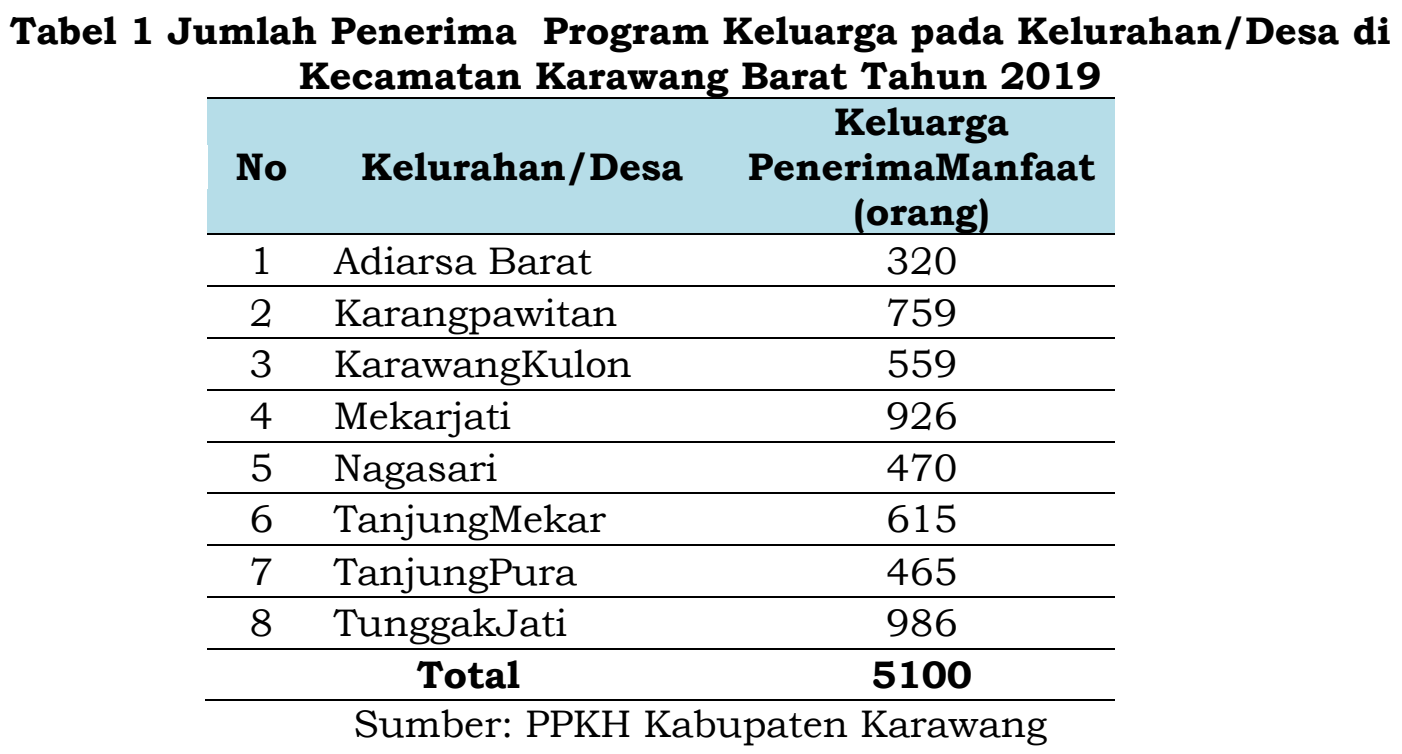

Dari data diatas dapat dijelaskan bahwa jumlah penerima $\mathrm{PKH}$ di Kecamatan Karawang Barat, sebanyak 8 kelurahan/desa. Paling banyak menerima PKH adalah Tunggak Jati sebanyak 986 orang, disusul Mekarjati sebanyak 926 orang, dan kemudian Karangpawitan sebanyak 759 orang.

Namun berdasarkan penelitian, Kebijakan Program keluarga Harapan ini masih belum optimal, dengan beberapa alasan-alasan seperti pertama, belum optimalnya kebijakan Program Keluarga Harapan. Kedua, kurangnya sumber daya pendamping atau sumber daya $\mathrm{PKH}$. Ketiga, masih cukup tingginya angka kemiskinan. Keempat, penyaluran programyang tidak merata. Kelima, kurangnya komunikasi dalam pelaksanaan program Keenam, penggunaan dana bantuan yang tidak semestinya/tidak tepat.

Atas dasar permasalahan tersebut peneliti mengkaji dan mencari berbagai penelitian sebelumnya yang telah banyak mengulas mengenai program PKH dalam berbagai perpektif, diantaranya penelitian berjudul "Implementasi Program Keluarga Harapan Dalam Menanggulangi Kemiskinan di Kecamatan Dawarblandong Kabupaten Mojokerto " oleh Khodiziah Isnaini Kholif, Irwan Noor, dan Siswidiyanto (2014) yang mengemukakan bahwa implementasi PKH belum optimal karena sosialisasi dan pendamping memiliki pekerjaan lain/double job), teori dalam penelitian ini menggunakan teori Sunggono (1994) faktor penghambat implementasi yaitu isi kebijakan, informasi, dukungan, pembagian potensi. Penelitian selanjutnya, berjudul "Implementasi Program Keluarga Harapan Dalam Upaya Mengentaskan Kemiskinan Di Kota Batu” oleh Cahyo Sasmito dan Ertien Rining Nawangsari (2019) yang mengemukakan bahwa masih adanya sikap dan watak yang apatis Peserta PKH. Data Peserta PKH masih ada yang belum akurat,kapasitas ruangan, sarana dan prasarana, yang terbatas, teori dalam penelitian ini menggunakan teori George C. Edward III (Agustino, (2012: 149-154) dengan 4 variabel yaitu (1) komunikasi; (2) sumberdaya; (3) disposisi atau sikap pelaksana; (4) struktur birokrasi. Selanjutnya yang berjudul "Implementasi Pemberdayaan Masyarakat Dalam Program Keluarga Harapan Untuk Memutus Rantai Kemiskinan Di Kota Malang" oleh Arif Citra Permana, Cahyo Sasmito, dan Cakti Indra Gunawan (2018) mengatakan bahwa ketidaksiapan program sehingga aturan-aturan yang 
mengaturnya masih sering berganti-ganti, teori dalam penelitian ini menggunakan teori George C. Edward III (Winarno,2016) dengan 4 variabel yaitu (1) komunikasi; (2) sumberdaya; (3) disposisi atau sikap pelaksana; (4) struktur birokrasi.

Keberhasilan PKH di Kecamatan Karawang Barat Kabupaten Karawang dapat dikatakan berhasil apabila hasil dari evaluasi kebijakan tersebut dapat memenuhi dimensi-dimensi yang dibutuhkan. Suatu kebijakan program yang telah dilaksanakan haruslah diukur melalui evaliasi agar hasil yang dicapai diketahui, apakah hasil tersebut sudah sesuai dengan apa yang diharapkan atau hasil tersebut jauh menyimpang dari yang diharapkan. Begitu juga dengan penelitian mengenai evaluasi kebijakan PKH di Kecamatan Karawang Barat Kabupaten Karawang, penulis akan melakukan kajian dan analisis yang ditemui di lapangan. Dalam penelitian ini, penulis menggunakan teori William N Dunn (2003:158) dengan indikator-indikator yang mempengaruhi evaluasi kebijakan publik yaitu efektivitas, efisiensi, kecukupan, perataan, dan ketepatan.

\section{METODE PENELITIAN}

Penelitian ini dilakukan dengan menerapkan metode deskriptif dengan pendekatan penelitian kualitatif. Sugiyono (2017:9) menyatakan bahwa metode penelitian kualitatif diartikan sebagai metode penelitian yang berlandaskan pada filsafat pospositivisme, digunakan untuk meneliti pada kondisi objek yang alamiah, (sebagai lawannya adalah eksperimen) dimana peneliti adalah sebagai instrumen kunci, analisis data bersifat indukti/kualitatif, dan hasil penelitian kualitatif lebih menekankan makna daripada generalisasi. karena dalam penelitian dekriptif ini menggambarkan suatu masalah sosial yang terjadi di lingkungan masyarakat mengenai permasalahan pelaksanaan kebijakan pogram PKH di Kecamatan Karawang Barat, Kabupaten Karawang. Adapun teknik pengumpulan data dilakukan dengan 2 teknik yaitu: Studi pustaka merupakan langkah awal dalam pengumpulan data dengan penelaahan berbagai literatur kepustakaan atau buku-buku mengenai PKH serta konsep evaluasi baik berupa artikel-artikel yang berkaitan dengan evaluasi dan PKH, media online atau media cetak serta bahan kepustakaan yang memberikan informasi mengenai pelaksanaan PKH di Kabupaten Karawang. Penulis telah menetapkan bahwa sasaran dalam permasalahan pelaksanaan PKH yang berada di Kecamatan Karawang Barat, Kabupaten Karawang.

Studi lapangan ini dilakukan dengan 2 teknik yaitu melalui observasi dan wawancara. Peneliti melakukan observasi dengan mengamati secara langsung segala bentuk kegiatan pihak-pihak pelaksana kebijakan program PKH dan masyarakat Kecamatan Karawang Barat. Sedangkan untuk wawanara dilakukan dengan Kepala Bidang Perlidungan Dan Jaminan Sosial selaku Pelaksana PKH Kabupaten Karawang, Koordinator Pendamping tingkat Kecamatan Karawang Barat, masyarakat keluarahan Tunggak Jati Kec Karawang Barat, masyarakat Tanjung Mekar Kec Karawang Barat dan masyarakat Mekarjari Kec Karawang Barat.

\section{HASIL DAN PEMBAHASAN}

Berdasarkan hasil wawancara akan dianalisis dengan tetap mengacu pada data sesuai dengan fokus kajian peneliti, dari seluruh data yang disajikan secara menyeluruh yang diperoleh selama penelitian. Berdasarkan hasil penelitian yang 
telah didapatkan, maka dapat dilakukan analisis Evaluasi Kebijakan Program Keluarga Harapan di Kecamatan Karawang Barat Kabupaten Karawang dengan menggunakan 6 indikator evaluasi kebijakan menurut William $\mathrm{N}$ Dunn (2003:158) yaitu efektifitas, efisiensi, kecukupan, pemerataan, responsivitas, dan ketepatan. Maka atas dasar temuan permasalahan di lapangan peneliti memutuskan untuk menganalis 5 dimensi yang bisa menggambarkan penelitian ini.

\subsection{Efektivitas}

Kriteria efektivitas berpedoman pada tujuan adanya kebijakan. Hasil dari pelaksanaan kebijakan diharapkan mampu mencapai tujuan-tujuan yang telah ditetapkan, sehingga suatu kebijakan bisa dianggap efektif. Peran pelaksana sangat dibutuhkan, Pelaksana kebijakan harus mampu mencapai tujuan kebijakan dalam menanggulangi kemiskinan melalui kebijakan program PKH.

Berdasarkan dari hasil penelitian bahwa pelaksanaan program $\mathrm{PKH}$ periode 2008 sampai 2020 dikatakan sudah efektif dalam membantu keluarga miskin secara ekonomi dan dapat menanggulangi kemiskinan di Kabupaten Karawang. Bisa diketahui berdasarkan sumber data yang peneliti peroleh dari BPS karawang dalam kurun waktu 5 tahun kebelakang bahwa upaya dan usaha pelaksana dalam melaksanakan program PKH hasilnya kemiskinan berhasil ditekan. Untuk memperkuat data terkait penurunan jumlah kemiskinan sebagai berikut:

Tabel 2 Penurunan Jumlah Pendududuk Miskin di Kabupaten Karawang periode 2015-2019

\begin{tabular}{ll}
\hline Tahun & Jumlah Penduduk Miskin \\
\hline 2015 & 235.030 Jiwa \\
\hline 2016 & 230.600 Jiwa \\
\hline 2017 & 236.480 Jiwa \\
\hline 2018 & 187.960 Jiwa \\
\hline 2019 & 173.660 Jiwa \\
\hline
\end{tabular}

Sumber: BPS Kabupaten Karawang

Dari tabel diatas upaya dan usaha pelaksana hasilnya angka kemiskinan inii berhasil ditekan sampai tahun 2019. Kemudian secara umum tujuan kebijakan Program PKH adalah untuk mengentaskan kemiskinan. Secara spesifik tujuam program keluarga harapan adalah membantu meringankan beban ekonomi dalam upaya meningkatkan kualitas pendidikan dan kesehatan. Tujuan kebijakan dicapai melalui tujuan sebagai berikut:

a) Menurunksn angka gizi buruk dan stunting;

b) Meningkatkan pencapaian pendidikan;

c) Menjadi episentrum program-program penanggulangan kemiskinan secara terintegrasi;

d) Meningkatkan inklusi keuangan pada kelompok masyarakat yang berpenghasilan rendah; 
Kemudian di Kabupaten karawang mendapatkan penghargaan peringkat pertama se-jawa barat atas berhasilnya dalam melaksanakan graduasi mandiri sebanyak $756 \mathrm{KPM}$, artinya sudah banyak masyarakat sudah mandiri atau mapan secara ekonomi tanpa bantuan sosial lagi. Peran pelaksana disini sangat dibutuhkan, pelaksana kebijakan harus mampu mencapai tujuan kebijakan dalam menanggulangi kemiskinan melalui kebijakan program PKH. Namun dibalik itu peneliti menemukan bahwa di Kecamatan Karawang Barat sendiri masih banyak keluarga miskin yang enggan melakukan graduasi mandiri karena salah satu faktor yaitu peserta PKH masih ingin mendapatkan bantuan sosial terus menerus, padahal komponen didalam keluarga sudah tidak ada lagi seperti contohnya anak yang sudah tamat sekolah SMA. Untuk di Kecamatan Karawang Barat masih belum efektif dalam pengawasan pada pelaksanaan kebijakan.

Di dalam pelaksanaan program $\mathrm{PKH}$, komitmen sangat penting yang harus dilakukan oleh peserta PKH. Bahwa berdasarkan hasil wawancara, peserta PKH pentingnya menjaga komitmen dan patuh terhadap kewajiban yang telah ditetapkan. Masyarakat di Kecamatan Karawang Barat sudah memenuhi komitmen yang ditetapkan dan telah menjalankan kewajibannya sebagai peserta PKH baik dari komponen pendidikan mapun kesehatan. Sanksi penting di buat untuk memberikan pengaruh taat kepada para penerima. Pemberian sanksi yang tegas dapat memberikan efek jera maupun rasa takut kepada KPM untuk tidak melanggar komitmennya. Tujuan PKH salah satunya adalah untuk merubah cara pola pikir para peserta KPM agar mereka mengerti betapa pentingnya kesehatan dan pendidikan anak-anaknya.

\subsection{Efisiensi}

Berkenaan dengan jumlah usaha yang diperlukan untuk meningkatkan tingkat efektivitas tertentu. Efisiensi yang merupakan sinonim dengan rasionalitas ekonomi, adalah merupakan hubungan antara efektivitas dan usaha yang terakhir umumnya diukur dari ongkos moneter. Kriteria ini memiliki 2 indikator yaitu sumber daya serta optimalisasi untuk mencapai hasil yang ideal atau maksimal.

Untuk mencapai tujuan, butuh adanya peran dari berbagai pihak yang dapat menjadi penunjang keberhasilan dari program PKH. Masing-masing intansi atau lembaga mempunyai tugas pokok dan fungsi yang berbeda. Pihak yang terkait dalam menunjang keberhasilam PKH merupakan satu kesatuan yang tidak dapat dipisahkan, beik pekayanan kesehatan, pendidikan, pendamping maupun petugas lainnya. Untuk SDM PKH di Karawang sebanyak 281 orang dengan berbagai tugasnya, yaitu supervisor, koordinator pendamping tingkat kabupaten, koordinator pendamping tingkat kecamatan, operator dan pendamping. Jumlah SDM ii bisa berubah yaitu salah satu faktornya adalah mengundurkan diri karena sudah mendapatkan pekerjaan yang lain. Satu hal yang mesti diketahui bahwa SDM PKH tidak bisa merangkap pekerjaan lain atau double job, dikhawatirkan fokusnya terbagi dengan pekerjaan yang lain. Namun, untuk sumber daya pendamping di Kabupaten Karawang sudah bagus dalam melaksanakan tugasnya hal ini dibuktikan dengan mendapatkan penghargaan dari kementrian sosial. Namun dibalik itu jumlah SDM pendamping di Kecamatan Karawang Barat terbilang masih kurang hanya ada 16 pedamping 
saja karena idealnya pemdamping hanya mendampingi 100 KPM tetapi pada kenyataannya pendamping mendampingi KPM sebanyak 200 sampai 400 KPM.

Berdasarkan hasil penelitian terkait Sumber daya anggaran yang dialokasi oleh pemerintah pusat untuk program bantuan sosial PKH pada tahun 2020 senilai 37 triliun dikarenakan adanya pandemi corona anggaran dinaikan sebesar 25\% dan bisa dicairkan tiap bulan selama pandemi, tidak seperti tahun sebelumnya dana bantuan cair per triwulan atau tiga bulan sekali. Dan jumlah dana bantuan untuk peserta PKH di Kecamatan Karawang Barat adanya tambahan 25\% yaitu pada tahap ke 2 saja periode bulan April-Juni. Anggaran program PKH ini adalah anggaran nasional, begitupun penyaluran langsung dari kementrian sosial kemudian ditransfer ke rekening peserta PKH.

Tabel 3 Skema Bantun Perbulan Tahun 2020

\begin{tabular}{ccccc} 
No & Kategori & $\begin{array}{c}\text { Indeks } \\
\text { Pertahun }\end{array}$ & $\begin{array}{c}\text { Indeks } \\
\text { Perbulan }\end{array}$ & $\begin{array}{c}\text { Tambahan } \\
\mathbf{2 5 \%}\end{array}$ \\
\hline 1 & Ibu Hamil & 3.000 .000 & 250.000 & 3.750 .000 \\
\hline 2 & Anak Usia Dini & 3.000 .000 & 250.000 & 3.750 .000 \\
\hline 3 & SD & 900.000 & 75.000 & 1.125 .000 \\
\hline 4 & SMP & 1.500 .000 & 125.000 & 1.875 .000 \\
\hline 5 & SMA & 2.000 .000 & 166.000 & 2.498 .000 \\
\hline 6 & Disabilitas & 2.400 .000 & 200.000 & 3.000 .000 \\
\hline 7 & Lanjut Usia & 2.400 .000 & 200.000 & 3.000 .000 \\
\hline \multicolumn{5}{c}{ Sumber: PPKH Kabupaten Karawang }
\end{tabular}

Kemudian peneliti menemukan bahwa dalam penyaluran dana bantuan kepada peserta KPM yang khususnya di Kecamatan Karawang Barat, bahwa pelaksanaan di Kecamatab Karawang Barat penyaluran bantuan disesuaikan dengan situasu dan kondisi yang ada pada tahun berjalan serta disesuaikan dengan kebijakan yang dibuat. Dalam prosedur peneriman uang bantuan pendamping hanya memberika informasi melalui ketua kemlompok PKH. Sebenarnya informasi dari mulut kemulut tidak efisien dalam kelancaran sebuah program karena informasi dari mulut ke mulut bisa saja berubah, hal ini bisa membuat peserta $\mathrm{PKH}$ menjadi ragu dan bingung mengenai informasi terebut. Dalam indikator efisiensi masih belum optimal dilihat dari segi sumber daya manusia dan dalam proses penyaluran dana bantuan sosial PKH.

\subsection{Kecukupan}

Berkenaan dengan seberapa jauh suatu tingkat efektivitas memuaskan kebutuhan, nilai atau kesempatan yang menumbuhkan adanya masalah. Kriteria kecukupan menekankan pada kuatnya hubungan antara alternatif kebijakan dan hasil yang diharapkan. Kriteria ini berkaitan dengan bagaimana hasil dari kebijakan dapat mengatasi masalah yang dialami masyarakat. Kecukupan dapat dikatakan sebagai terpenuhinya segala kebutuhan atau keperluan hajat hidup keluarga sangat miskin baik berupa kebutuhan jasmani maupun rohani, dengan kata lain kecukupan adalah menyangkut terpenuhinya kebutuhan dasar keluarga miskin terutama akan kebutuhan sandang, papan dan pangan dan juga kebutuhan akan pendidikan dan kesehatan. 
Berdasarkan hasil penelitian bahwa dari pelaksanaan $\mathrm{PKH}$ ini program untuk menanggulangi kemiskinan, program ini memberikan efek yang sangat positif bagi masyarakat karena masyarakat tidak terbebani lagi secara ekonomi, pendidikan dan kesehatan. Sebelum adanya program keluarga harapan masyarakat acuh terkait kesehatan dan pendidikan anaknya, dalam hal pendidikan dahulu sebelum adanya program PKH tingkat pendidikan pada kpm kebayakan lulus SD atau SMP saja disebabkan masyarakat tidak mampu secara ekonomi untuk meneruskan pendidikan anaknya, padahal pemerintah mewajibkan belajar 12 tahun. Begitupun dalam hal kesehatan, peserta $\mathrm{PKH}$ awalnya tidak tahu bagaimana merawat kesehatan kehamilan dan anak yang masih balita. Dengan adanya program PKH ini masyarakat bisa hidup dengan mapan dan SDM yang meningkat. Pada saat ini para peserta PKH sudah paham bahwa kesehatan dan pendidikan sangat penting bagi kehidupan keluarganya. Dalam indikator kecukupan sudah optimal karena keluarga miskin mendapatkan keringanan secara ekonomi dan anak-anak bisa hidup terjamin dari aspek pendidikan dan kesehatan. Lalu respon pada pelaksanaan PKH di Kecamatan Karawang Barat mendapatkan respon yang positif dari pihak pedamping mapupun dari masyarakat penerima bantuan $\mathrm{PKH}$.

Peneliti menemukan bahwa dalam keberhasilan kebijakan program PKH di Kecamatan Karawang Barat, Kebijakan program $\mathrm{PKH}$ sudah memberikan kepuasan baik dari segi pelayanan kesehatan dan pendidikan maupun KPM dan Kebijakan program PKH memperoleh dukungan yang positif dari masyarakat.

\subsection{Perataan}

Berhubungan dengan rasionalitas legal dan sosial dan menunjuk pada distribusi akibat dan usaha antara kelompok-kelompok yang berbeda dalam masyarakat. Kebijakan yang berorientasi pada perataan adalah kebijakan yang pada akibatnya (misalnya, unit pelayanan atau manfaat moneter) atau usaha (misalnya, biaya moneter) secara adil didistribusikan. Kriteria ini memiliki 2 indikator yaitu pencapaian sasaran dan akuntabilitas.

Berdasarkan hasil penelitian dan wawancara peneliti menemukan bahwa pada pencapaian sasaran proses tidak meratanya penyebaran program $\mathrm{PKH}$ ditandai dengan masih terdapatnya masyarakat yang belum mendapatkan bantuan dari PKH. Untuk Kecamatan Karawang Barat dalam hal pemerataan belum mendapatkan hasil yang memuaskan. Ketidakmerataan pada proses pelaksanaan PKH yaitu dari data penduduk miskin sebanyak 7,645 jiwa penduduk di Kecamatan Karawang Barat dan yang sudah terdaftar mendapatkan bantuan sebanyak 5,100 KPM. Dari data tersebut dapat terlihat bahwa jumlah masyarakat yang belum tersentuh bantuan PKH belum mencakup semua penduduk pra sejahtera di Kecamatan Karawang Barat secara keseluruhan. Sebenarnya mereka yang tergolong miskin masik bisa mendapatkan dana bantuan dari program pemerintah yang lain misalnya BPNT dan Rastra (beras ejahtera), tetapi kebanyakan masyarakat ingin sekali mendapatkan bantuan PKH dikarenakan untuk memenuhi kebutuhan pendidikan anaknya agar tetap melanjutkan sampai lulus SMA, dan bidang kesehatan untuk memenuhi gizi ibu mengandung dan balita. 
Tabel 4 Penduduk Miskin di Kecamatan Karawang Barat Tahun 2019

\begin{tabular}{|c|c|c|c|}
\hline \multirow{7}{*}{$\begin{array}{l}\text { Kecamatan } \\
\text { Karawang } \\
\text { Barat }\end{array}$} & Usia Dini & 1234 & \multirow{7}{*}{$\begin{array}{c}\text { Total } \\
7645 \text { Jiwa }\end{array}$} \\
\hline & Ibu Hamil & 27 & \\
\hline & Lansia & 329 & \\
\hline & Disabilitas & 38 & \\
\hline & Anak SD & 2774 & \\
\hline & Aank SMP & 1755 & \\
\hline & Anak SMA & 1488 & \\
\hline
\end{tabular}

Berdasarkan hasil penelitian pertanggungjawaban masih belum memenuhi dalam pelaksanaanya, hal tersebut dikarenakan masalah ketidaksesuaian data dengan kondisi dilapangan. Dari pihak pendamping dan desa yang lebih mengerti tentang kodisi di lapangan dari desa sering mengeluh data dari pusat yang tidak kunjung diperbaharui. Sehingga keluarga miskin yang belum mendapatkan serig mengeluh kepada pihak desa karena terbatasnya kuota $\mathrm{PKH}$, hal ini mempengaruhi akuntabilitas dalam pelaksanaan program PKH yaitu sulitnya mengajukan penambahan kuota PKH oleh pihak desa.

\subsection{Ketepatan}

Berhubungan dengan rasional substantif, karena pertanyaan tentang ketetapan kebijakan tidak berkenaan dengan satuan kriteria individu tetapi dua atau lebih kriteria secara bersama-sama. Ketetapan menunjuk pada nilai atau harga dari tujuan-tujuan kebijakan dan kepada kuatnya asumsi yang melandasi tujuan tersebut apakah pemilihan alternatif kebijakan yang dicapai dapat benarbenar bermanfaat bagi kelompok sasaran.

Berdasarkan hasil penelitian peneliti menemukan bahwa pelaksanaan kebijakan program PKH ini berguna bagi masyarakat miskin atau keluarga miskin karena dapat meringankan beban ekonomi. Masyarakat merasa terbantu dengan adanya bantuan sosial PKH, selain itu dengan adanya bantuan ini anakanak peserta PKH memiliki harapan masa depan yang lebih baik dan kesempatan untuk melanjutkan sekolah wajib 12 tahun. Akan tetatapi kebanyakan peserta PKH di Kecamatan Karawang Barat masih menggunakan bantuan diluar kepentingan program, tetapi untuk kebutuhan sehari-hari dan kepentingan pribadi. Kemudian bantuan yang diberikan belum bermanfaat sepenuhnya untuk KPM. Hal ini dikarenakan sebagian besar peserta masih tidak mau untuk memanfaatkan dana bantuan yang diterima untuk meningkatkan lagi secara ekonomi bagi keluarga mereka dengan cara berwirausaha. Melalui pertemuan kegiatan Family Development Session (FDS) terkait kewirausahaan masih belum dipraktikan oleh KPM. Jika masyarakat mampu merubah cara pola pikir menjadi lebih maju merka akan memanfaatkan dana bantuan yang diterima untuk membuka usaha agar bisa menambah pendapatan keluarga. Dengan demikian kedepannya mereka dapat keluar dari lingkar kemiskinan.

Kemudian peneliti menemukan permasalahan yang menjadi tolak ukur keberhasilan dalam ketepatan program PKH di Kecamatan Karawang Barat. Antara lain yaitu kurangnya monitoring dari pihak dinas terkait, pemerintah kelurahan atau kecamatan belum adanya pembaharuan/update data masyarakat sehingga menimbulkan permasalahan di lapangan seperti aduan 
dari masyarakat yang belum tersentuh bantuan PKH. Pihak-pihak yang terkait seperti RT/RW pejabat yang terdekat dengan masyarakat harusnya dapat membantu ketika masyarakat kesulitan ketika ingin mengajukan menjadi peserta bantuan PKH secara adil dan merata tanpa adanya pilih kasih. Maka pemerintah dan pihak yang terkait dalam hal bantuan progran $\mathrm{PKH}$ agar melakukan pengawasan secara intens dan melakukan evaluasi untuk monitoring agar program PKH tepat sasaran.

\section{PENUTUP}

Berdasarkan pada hasil penelitian di atas maka peneliti menarik simpulan bahwa evaluasi kebijakan program PKH dalam menanggulangi kemiskinan di Kecamatan Karawang Barat belum sepenuhnya optimal, hal tersebut dikarenakan penyaluran bantuan yang tidak merata, kekurangan sumber daya manusia dalam melaksanakan program $\mathrm{PKH}$, informasi penyaluran tidak optiimal karena masih melalui informasi dari mulut ke mulut dan susahnya mengubah cara pola pikir peserta PKH. Meski begitu upaya dan usaha pihak yang terkait dalam menanggulangi kemiskinan ini berhasil ditekan.

Dari permasalahan yang telah diuraikan tersebut, maka peneliti memberikan rekomendasi kepada Dinas Sosial, Kecamatan Karawang Barat dan pihak-pihak yang terkait antara lain : Untuk pedamping dalam program bantuan PKH kepada pseserta PKH sebaiknya memberikan edukasi perihal penggunaan uang dari bantuan $\mathrm{PKH}$ ini, mendorong peserta mempergunakan dana yang diperoleh sebaik-baiknya untuk tujuan program. Dan pendamping $\mathrm{PKH}$ harus mampu untuk mengarahkan dan lebih giat memfokuskan pada proses merubah cara pola pikir masyarakat melalui pembinaan-pembinaan atau P2K2 agar tidak tergantung pada bantuan PKH. Dengan demikian, diharapkan dimasa yang akan mendatang mampu meningkatkan kualitas hidup yang mapan.

Untuk pihak Kecamatan mengajukan penambahan pendamping PKH sebaiknya dilakukan karena di Kecamatan Karawang Barat sendiri dengan peserta PKH sebanyak 5.100 KPM hanya mempunyai 16 pendamping, untuk mendapatkan hasil yang memuaskan harus dilakukan penambahan sebagai upaya untuk memudahkan dalam mandampingi dan mengawasi. Pendamping dan pihak Kelurahan sebagai pelaksana program harus memberikan sosialisasi bagi masyarakat yang tidak mendapatkan bantuan agar tidak menimbulkan kecemburuan sesama masyarakat, karena pendamping dan pihak kelurahan lebih tahu kondisi dilapangan. Untuk pemerintah Kecamatan maupun Dinas Sosial terkait masyarakat yang belum mendapatkan program dengan perlu adanya pembaruan data dan mengajukan kuota untuk peserta $\mathrm{PKH}$, sesuai dengan kondisi masyarakat miskin yang lebih berhak menerima. Dan terkait pola bantuan PKH ini perlu dibatasi masanya, tidak baik apabila masyarakat ketergantungan menerima selama selama 10 tahun lebih program ini secara terus menerus, akan tetapi dari mereka tidak ada perubahan tetap diposisi yang sama. Untuk penggunaan anggararan maupun penyalurannya dalam hal ini Dinas Sosial dan Kecamatan Karawang Barat yang terkait dalam pelaksanaan kebijakan program harus menigkatkan pengawasan dalam penyaluran dana bantuan PKH maupun dalam validasi dan verifikasi calon peserta $\mathrm{PKH}$ secara prosedural agar program PKH lebih terarah dan tepat sasaran. 


\section{DAFTAR PUSTAKA}

Badan Pusat Statistik. 2019, juli 15. Presentase Penduduk Miskin.https://www.bps.go.id/pressrelease/2019/07/15/1629/presentase -penduduk-miskin-maret-2019-sebesar-9-41-persen.html. Diakses tanggal 7 maret 2020

Dunn, William N. 2003. Pengantar Analisis Kebijakan Publik, Edisi Kedua. Yogyakarta: Gadjah Mada University press

Joglo Abang. 2018, Maret 05. Permensos Program Keluarga Harapan.https://www.jogloabang.com/sosial/permensos-1-2018-programkeluarga-harapan. Diakses tanggal 7 maret 2020

Sugiyono. (2017). Metode Penelitian Kuantitatif, Kualitatif dan R\&D. Bandung: Alfabeta

Jurnal:

Arif citra permana, cahyo sasmito, cakti indra gunawan. Universitas tribhuwana tunggadewi malang (2018). Implementasi pemberdayaan masyarakat dalam program keluarga harapan untuk memutus rantai kemiskinan di kota malang

Cahyo sasmito dan ertien rining nawangsari. Universitas Pembangunan Veteran Jawa Timur (2019). Implementasi program keluarga harapan dalam upaya mengentaskan kemiskinan di kota batu

Khodiziah isnaini kholif, irwan noor, siswidiyanto. Universitas Brawijaya, malang (2014). Implementasi program keluarga harapan dalam menanggulangi kemiskinan di kecamatan dawarblandong kabupaten mojokerto

Peraturan Perundang-undangan:

Peraturan Pemerintah Republik Indonesia Nomor 63 Tahun 2013 tentang Pelaksanaan Upaya Penanganan Fakir Miskin Melalui Pendekatan Wilayah, (Lembaran Negara Republik Indonesia Tahun 2013 Nomor 157, Tambahan Lembaran Negara Republik Indonesia Nomor 5449).

Peraturan Menteri Sosial Republik Indonesia Nomor 1 Tahun 2018 tentang Program Keluarga Harapan, (Berita Negara Republik Indonesia Tahun 2018 Nomor 187).

Pedoman Pelaksanaan PKH Tahun 2019

Undang-Undang Republik Indonesia Nomor 13 Tahun 2011 tentang Penanganan Fakir Miskin, (Lembaran Negara Republik Indonesia Tahun 2011 Nomor 83, Tambahan Lembaran Negara Republik Indonesia Nomor 5235). 